\title{
Prevalence of hemoglobinopathies in different regions and castes of Uttar Pradesh, India -A hospital based study
}

\author{
Pratima Verma1, Archna Ghildiyal2 ${ }^{2}$ Dileep Verma², Akhilesh Krishna1, Shraddha Singh ${ }^{3}$, Ashutosh Kumar ${ }^{4}$, \\ Sunita Tiwari ${ }^{3}$
}

${ }^{1}$ PhD, Department of Physiology, King George's Medical University, Lucknow, Uttar Pradesh, India, ${ }^{2}$ Associate Professor, Department of Physiology, King George's Medical University, Lucknow, Uttar Pradesh, India, ${ }^{3}$ Professor, Department of Physiology, King George's Medical University, Lucknow, Uttar Pradesh, India, ${ }^{4}$ Professor, P.G. Department of Pathology, King George's Medical University, Lucknow, Uttar Pradesh, India

\section{A B S T R A C T}

Background: Thalasemia and other hemoglobinopathies are found in all the states of India and their prevalence is quite variable. In Uttar Pradesh very few studies are found which explore the spectrum of hemoglobinopathies. There is no such study which identifies the geographic distribution of high-risk communities with frequencies of hemoglobinopathies. Aim: Present study was carried out to determine the prevalence of hemoglobinopathies in different regions and castes of Uttar-Pradesh (UP) state. Materials and Methods: This is a preliminary community based cross-sectional, hospital based study, conducted at King George's Medical University, Lucknow, Uttar- Pradesh. Subjects aged between 18 to 65 years were enrolled for sampling. The anticoagulated blood was used for performing CBC (complete blood count), and hemoglobin electrophoresis to measure hemoglobinopathies. Results: The present study revealed higher $(28 / 194 ; 19.5 \%, p<0.05)$ prevalence of hemoglobinopathies in Lucknow district as compared to other districts of Uttar-Pradesh and Brahmin caste having high frequency $(33 / 112 ; 29.5 \%)$ followed by Jaiswal $(3 / 13 ; 23.1 \%)$ and Arora $(2 / 9 ; 22.2 \%)$. Conclusion: The data regarding prevalence and distribution can be useful in prevention and management of various hemoglobinopathies which play a vital role in the hospital blood bank as well as in the formulation of transfusion policies.
Access this article online

Website:

http://nepjol.info/index.php/AJMS

10.3126/ajms.v6i5.12339

\section{INTRODUCTION}

India has multiple geographical, ethnic, religious and language divisions. ${ }^{1}$ Traditionally, marriages are within these subdivisions only resulting in difficulties in estimating the burden of genetic diseases at local and national level. In India, the gene frequency of hemoglobinopathies is $4.2 \%$, with a population over 1 billion and over 12000 infants born each year have a clinically significant hemoglobinopathies. ${ }^{2}$ According to world health organization (WHO), 5\% of the world population is a carrier for Hemoglobin disorders. ${ }^{3}$ Within this overall disease classification, a 1989 WHO Working Group on guidelines for the control of haemoglobin disorders estimated a 3.9\% carrier frequency for $\beta$-thalasemia in India, encompassing all types of $\beta$ -thalasemia trait. ${ }^{4}$
In various parts of India, the prevalence of $\beta$-Thalasemia is different: $6.5 \%$ in Punjab, $8.4 \%$ in Tamilnadu, $4.3 \%$ in south India, and $3.5 \%$ in Bengal. $\beta$ - Thalasemia has a high prevalence in some communities, such as Sindhi, Luvana, Tribes, and Rajputs. The incidence of $\beta$-Thalasemia in Gujarat is $10 \%$ to $15 \% .{ }^{5}$ In the studies from north India, major groups of Thalassemics from Uttar Pradesh (UP) are the migrant ethnic populations of Punjab and Sindh origin. $^{6-10}$

Normally, the variation of Thalasemia trait and sickle cell hemoglobinopathies in India is between 3-17\% and 1-44\% respectively. Approximately 30 million Indians are carriers of $\beta$-Thalasemia and 7000 babies with $\beta$-Thalasemia are born every year. In different ethnic groups, the variation in carrier rate is between $0 \%-17 \%{ }^{11}$ 
Although Thalasemia and other hemoglobinopathies are found in all the states of India and their prevalence is quite variable, very few studies are found in Uttar-Pradesh which explores the spectrum of hemoglobinopathies. There is no such study, which identifies the geographic distribution of high-risk communities with frequencies of hemoglobinopathies.

Therefore preliminary hospital based study was carried out to determine the Prevalence of hemoglobinopathies in different regions and castes of Uttar-Pradesh state.

\section{MATERIALS AND METHODS}

This is a preliminary community based cross-sectional study conducted in the Department of Physiology with the collaboration of P.G. Department of Pathology at Kings George's Medical University (KGMU), Lucknow, U.P. between Sept. 2011 to Dec.2013. People of age group between 18 to 65 years were randomly selected from Out-patient-department (OPD) on the basis of inclusion and exclusion criteria (included the suspected cases of hemolytic anemia without any systemic / chronic infection and drug abuse). An informed consent was obtained from the participants prior to the commencement of screening. The prepared questionnaires were provided to all the participants containing information related with age, sex, resident, nationality, educational qualification, occupation and financial status. The study was approved by Institutional ethics committee Kings George's Medical University, Lucknow, UP, India.

\section{Sample collection and Preparation}

Six $\mathrm{ml}$ venous blood was collected in EDTA vials and few drops of fresh whole blood were put on slides for blood group investigation. The anticoagulated blood was used for performing CBC (complete blood count) and hemoglobin electrophoresis. Haemolysate was prepared from whole blood by using saline and carbon tetra chloride with a concentration of $1.6 \mathrm{~g} / \mathrm{dl}$ to $2.2 \mathrm{~g} / \mathrm{dl}$ for hemoglobin electrophoresis. ${ }^{12}$

\section{Complete Blood Count}

Hematological indices were measured using Sysmex MX- 4 fully automated blood cell counter, which was calibrated with commercially available controls. The sickling test was performed using freshly prepared sodium metabisulphite solution as a reducing agent. ${ }^{13}$

\section{Electrophoresis}

Agarose gel electrophoresis was performed using Tris- EDTA -borate buffer at alkaline $\mathrm{pH}$ (8.6). The electrophoresis pattern was visualized by staining the film with a Ponceau S stan. This pattern was then quantified using a densitometer (Beckman Coulter) at $600 \mathrm{~nm}$ wavelength. ${ }^{12,14}$

\section{Statistical Analysis}

The collected data was checked and entered on Microsoft Excel Worksheet. Frequencies and percentages were used to describe categorical variables. The frequencies of nominal variables were compared by using the chi-square test. A p-value of $\leq 0.05$ was considered statistically significant. The Indian society is fragmented into thousands of caste groups and more than 500 tribal groups including 75 primitive communities (Indian STs, govt. doc, 2011).

\section{RESULTS}

Total 1180 subjects were screened for assessing hemoglobinopathies and among them, 143 subjects were detected for hemoglobinopathies with its prevalence being $12.1 \%$. The subjects belonged to different districts of UP state. Prevalence was analysed on the basis of presence or absence of hemoglobinopathy in the screened anemic $(\mathrm{Hb}<7 \mathrm{gm} \%)$ cases. The results were tabulated as follows:

\section{DISCUSSION}

The Indian population comprises numerous castes and communities, each revealing different genetic traits. Some hemoglobinopathies are also thalasemias but most are not. The distribution of beta-thalasemia is not uniform in Indian subcontinent. ${ }^{15-20}$ The highest frequency of beta thalasemia trait is reported in Gujarat (10-15\%), followed by Sindh (10\%), Punjab (6.5\%), Tamil Nadu (8.4\%) and Maharashtra. ${ }^{20,21}$

In our study, total screened subjects belonging from UP were 1180 in which 143 (12.1\%) were having hemoglobinopathies. Ambekar et al. reported the frequency of hemoglobinopathies in Western Maharashtra stating $106(26.5 \%)$ out of 400 subjects showing the presence of hemoglobinopathies. ${ }^{18}$ Chopra et al. revealed that out of 1032 participant, $258(25 \%)$ cases had abnormal hemoglobin. ${ }^{19}$ The issue of hemoglobinopathies in India is aggravated by the diversity of population. The gene frequency for various hemoglobinopathies varies across different regions of India. The rates of fertility, literacy and consanguinity in marriages are also diversified.

However, Patel J et al. reported the prevalence of hemoglobinopathies in Gujarat, mentioning that out of 428 subjects, $153\left(35.7 \%\right.$ ) had hemoglobinopathies ${ }^{20}$ while their another study in year 2011 found higher prevalence 


\begin{tabular}{|c|c|c|c|c|}
\hline Variables & $\begin{array}{c}\text { No of } \\
\text { subjects }\end{array}$ & $\begin{array}{l}\text { Subjects with } \\
\text { Hemoglobino- } \\
\text { pathy }\end{array}$ & $\begin{array}{l}\text { Prevalence } \\
\text { (\%) }\end{array}$ & p-value \\
\hline \multicolumn{5}{|l|}{ Age in years } \\
\hline$<20$ & 86 & 20 & 23.3 & $0.005^{*}$ \\
\hline $20-29$ & 396 & 51 & 12.9 & \\
\hline $30-39$ & 402 & 45 & 11.2 & \\
\hline $40-49$ & 296 & 27 & 9.1 & \\
\hline \multicolumn{5}{|l|}{ Gender } \\
\hline Male & 804 & 110 & 13.7 & $0.01^{*}$ \\
\hline Female & 376 & 33 & 8.8 & \\
\hline \multicolumn{5}{|l|}{ Income } \\
\hline HIG & 19 & 1 & 5.3 & $0.002^{*}$ \\
\hline MIG & 814 & 82 & 10.1 & \\
\hline LIG & 347 & 60 & 17.3 & \\
\hline \multicolumn{5}{|l|}{ Education } \\
\hline Illiterate & 101 & 27 & 26.7 & $0.0001^{*}$ \\
\hline Middle & 226 & 36 & 15.9 & \\
\hline High School & 273 & 40 & 14.7 & \\
\hline Intermediate & 233 & 16 & 6.9 & \\
\hline Graduate & 175 & 13 & 7.4 & \\
\hline $\begin{array}{l}\text { Above } \\
\text { graduate }\end{array}$ & 172 & 11 & 6.4 & \\
\hline \multicolumn{5}{|l|}{$\begin{array}{l}\text { Socio-economic } \\
\text { status }\end{array}$} \\
\hline 1 & 349 & 62 & 18.0 & $0.0001^{*}$ \\
\hline II & 193 & 32 & 16.6 & \\
\hline III & 262 & 29 & 11.1 & \\
\hline IV & 274 & 12 & 4.0 & \\
\hline V & 102 & 8 & 7.8 & \\
\hline \multicolumn{5}{|l|}{ Family size } \\
\hline$<6$ & 542 & 52 & 9.6 & $0.01^{*}$ \\
\hline$>=6$ & 638 & 91 & 14.3 & \\
\hline
\end{tabular}

up to $38.97 \% .{ }^{21}$ Another study by Panda A et al. based on West Bengal population illustrated to prevalence of hemoglobinopathies was $20.47 \%{ }^{22}$ Sachdev et al. reported $327(12.6 \%)$ hemoglobinopathies out of 2600 subjects. ${ }^{23}$ This finding is consistent with our result.

Contrary to our result, a study of Bangladesh in year 2012 reported that, out of 600 screened individuals, 253 (42.2\%) were found normal and $347(57.8 \%)$ had one or the other form of hemoglobinopathies. ${ }^{24}$ This frequency of hemoglobinopathies is higher in comparison to our findings. Most of the hemoglobinopathies belongs to the age group $<20$ years and the second common age group 20-29 years. It may be because of the average life span of

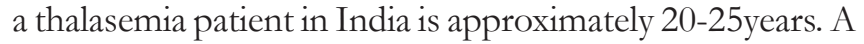
study by Jain et al. observed that $54.15 \%$ patients were of age group 13-36 years, $39.88 \%$ of age $0-12$ years. ${ }^{25}$ This finding is supported by our study. However, Uddin et al., (2012), observed to majority of hemoglobinopathy cases belong to neonatal to childhood period ( $0-15$ years) followed by reproductive age group (16-45 years) and only a few cases of old age ( $\geq$ 46years) were detected in Bangladesh. ${ }^{24} \mathrm{~A}$ work done on blood donors found that the age of the subjects with hemoglobinopathies were 21-30 years. ${ }^{21}$ All these studies revealed about varying

\begin{tabular}{|c|c|c|c|}
\hline S. N. & $\begin{array}{l}\text { District } \\
\text { ( } n=\text { No. of subject) }\end{array}$ & $\begin{array}{l}\text { No.of subjects with } \\
\text { Hemoglobinopathies } \\
\qquad(n=143)\end{array}$ & $\begin{array}{l}\text { Prevalence } \\
\%\end{array}$ \\
\hline 1 & Agra $(n=3)$ & 0 & 0.0 \\
\hline 2 & Aligarh $(n=1)$ & 1 & 0.70 \\
\hline 3 & Allahabad $(n=43)$ & 6 & 4.19 \\
\hline 4 & Ambedkar Nagar $(n=21)$ & 7 & 4.89 \\
\hline 5 & Amethi $(n=7)$ & 2 & 1.39 \\
\hline 6 & Azamgarh $(n=25)$ & 4 & 2.79 \\
\hline 7 & Badaun $(n=1)$ & 1 & 0.70 \\
\hline 8 & Bahraich $(n=43)$ & 5 & 3.49 \\
\hline 9 & Baliya $(n=7)$ & 0 & 0.0 \\
\hline 10 & Balrampur $(n=10)$ & 0 & 0.0 \\
\hline 11 & Banda $(n=8)$ & 1 & 0.70 \\
\hline 12 & Barabanki $(n=44)$ & 8 & 5.59 \\
\hline 13 & Bareilly $(n=16)$ & 0 & 0.0 \\
\hline 14 & Basti $(n=45)$ & 8 & 5.59 \\
\hline 15 & Bijnaur $(n=3)$ & 1 & 0.70 \\
\hline 16 & Buland Shahar $(n=9)$ & 0 & 0.0 \\
\hline 17 & Chanduali $(n=5)$ & 1 & 0.70 \\
\hline 18 & Devaria $(n=7)$ & 1 & 0.70 \\
\hline 19 & Etawah $(n=2)$ & 0 & 0.0 \\
\hline 20 & Faizabad $(n=38)$ & 10 & 6.99 \\
\hline 21 & Farrukhabad $(n=2)$ & 0 & 0.0 \\
\hline 22 & Fatehpur $(n=19)$ & 3 & 2.09 \\
\hline 23 & Ghazipur $(n=14)$ & 1 & 0.70 \\
\hline 24 & Gonda $(n=31)$ & 7 & 4.89 \\
\hline 25 & Gorakhpur (n=31) & 4 & 2.79 \\
\hline 26 & Hardoi $(n=42)$ & 6 & 4.19 \\
\hline 27 & Jaunpur $(n=35)$ & 5 & 3.49 \\
\hline 28 & Jhansi $(n=2)$ & 0 & 0.0 \\
\hline 29 & Kannauj $(n=7)$ & 0 & 0.0 \\
\hline 30 & Kanpur City $(n=36)$ & 7 & 4.89 \\
\hline 31 & Kanpur Dehat $(n=3)$ & 2 & 1.39 \\
\hline 32 & Kaushambi $(n=8)$ & 0 & 0.0 \\
\hline 33 & Kushi Nagar $(n=16)$ & 6 & 4.19 \\
\hline 34 & Lakhimpur $(n=54)$ & 6 & 4.19 \\
\hline 35 & Lucknow $(n=194)$ & 28 & 19.58 \\
\hline 36 & Maharaj Ganj $(n=16)$ & 4 & 4.79 \\
\hline 37 & Mainpuri $(n=3)$ & 0 & 0.0 \\
\hline 38 & Mau $(n=7)$ & 1 & 0.70 \\
\hline 39 & Meerut $(n=4)$ & 1 & 0.70 \\
\hline 40 & Muzaffar Nagar $(n=15)$ & 3 & 2.09 \\
\hline 41 & Pilibhit $(n=14)$ & 3 & 2.09 \\
\hline
\end{tabular}

hemoglobinopathy frequency according age group as well as geographical area. Our findings are highlighted to the facts of hemoglobinopathies. Patients have increased mortality and very few of them survive beyond the fifth decade.

The present study (Table 1) revealed higher prevalence of hemoglobinopathies in males 110/804(13.7\%) as compared to females 33/376(8.8\%). A study by Chopra and co-workers reported that out of 258 abnormal cases, $136(53 \%)$ were males and $122(47 \%)$ were females ${ }^{19}$ and Patel et al. found $62 \%$ male $37.9 \%$ female having hemoglobinopathies. ${ }^{20}$ Rao et al.,(2010) observed $32.4 \%$ males and $67.6 \%$ females were suffering from hemoglobin disorders ${ }^{26}$ while Uddin et al., (2012) reported an equal incidence 


\begin{tabular}{|c|c|c|c|c|}
\hline S.No. & Sub-castes & $\begin{array}{l}\text { No. of } \\
\text { subjects }\end{array}$ & $\begin{array}{c}\text { No. of } \\
\text { Haemoglobinopathies }\end{array}$ & $\begin{array}{c}\text { Prevalence of } \\
\text { Haemoglobinopathies }\end{array}$ \\
\hline 1 & Agarwal & 28 & 2 & 7.1 \\
\hline 2 & Yadav & 107 & 11 & 10.3 \\
\hline 3 & Ahmed & 16 & 2 & 12 \\
\hline 4 & Ali & 17 & 1 & 5.9 \\
\hline 5 & Ansari & 20 & 1 & 5.0 \\
\hline 6 & Arora & 9 & 2 & 22.2 \\
\hline 7 & Badhai & 14 & 2 & 14.3 \\
\hline 8 & Balmiki & 12 & 1 & 8.3 \\
\hline 9 & Bengali & 11 & 1 & 9.1 \\
\hline 10 & Jaiswal & 13 & 3 & 23.1 \\
\hline 11 & Brahman & 112 & 33 & 29.5 \\
\hline 12 & Bedi & 9 & 1 & 11.1 \\
\hline 13 & Harijan & 55 & 9 & 16.4 \\
\hline 14 & Chauhan & 10 & 1 & 10.0 \\
\hline 15 & Dhanuk & 10 & 1 & 10.0 \\
\hline 16 & Gadariya & 14 & 2 & 14.3 \\
\hline 17 & Gautam & 13 & 1 & 7.7 \\
\hline 18 & Gupta & 85 & 4 & 4.7 \\
\hline 19 & Jaat & 11 & 1 & 9.1 \\
\hline 20 & Jain & 15 & 1 & 6.7 \\
\hline 21 & Jatav & 14 & 2 & 14.3 \\
\hline 22 & Kahar & 15 & 1 & 6.7 \\
\hline 23 & Kashyap & 25 & 3 & 12.0 \\
\hline 24 & Kayasth & 36 & 6 & 16.7 \\
\hline 25 & Kewat & 8 & 1 & 12.5 \\
\hline 26 & Khan & 19 & 1 & 5.3 \\
\hline 27 & Kurmi & 72 & 6 & 8.3 \\
\hline 28 & Lodhi & 19 & 2 & 10.5 \\
\hline 29 & Maurya & 23 & 3 & 13.0 \\
\hline 30 & Paasi & 67 & 9 & 13.4 \\
\hline 31 & Paal & 34 & 2 & 5.9 \\
\hline 32 & Rajbhar & 19 & 2 & 10.5 \\
\hline 33 & Thakur & 109 & 11 & 10.1 \\
\hline 34 & Sekh & 12 & 1 & 8.3 \\
\hline 35 & Sikh & 14 & 2 & 14.3 \\
\hline 36 & Sonar & 21 & 2 & 9.5 \\
\hline 37 & Sunni & 26 & 4 & 15.4 \\
\hline 38 & Others & 56 & 5 & 8.9 \\
\hline
\end{tabular}

of hemoglobinopathies in both males and females. ${ }^{24}$ Considering our result, it may be due to difference in sex predilection to hemoglobinopathies and more pronounced difference in the type of hemoglobinopathies acquired within a geographical area or males are more aware towards their health as compared to females.

In our study (Table 2) Lucknow district had shown highest frequency of hemoglobinopathy 28/194(19.5\%), followed by Faizabad 10/38 (6.99\%), Ambedkar Nagar 7/21(4.89\%), Banda 1/8(4.89\%), Allahabad 6/43(4.19\%) and Bahraich 5/43(3.49\%). Aligarh, Badaun, Pilibhit, and Sant Kabir Nagar had shown lower frequency of hemoglobinopathies. This difference might be due to the local residents of Lucknow attending the KGMU-OPD who were more in number than those residing in rural areas.

The present study revealed the prevalence of hemoglobinopathies according to caste (Table 3). Brahmin caste having high frequency 33/112 (29.5\%) followed by Jaiswals 3/13(23.1\%) and Arora 2/9(22.2\%). The prevalence of hemoglobinopathies was almost similar among Kayasth, SC and Sunni. Badhai, Bedi, Gadariya, Jatav, Passi, Sikh, Kewat, Kashyap, Thakur, Yadav, Ahmed, Rajbhar have $<15 \%$ and the remaining castes showed $\leq 10 \%$ prevalence. This might be due to higher population of Brahmins as compared to others reported to the hospital.

A study of Odisha (Orissa) state by Bhasin MK et al., 1994 reported that hemoglobinopathy is confined mostly to scheduled tribes(ST) or scheduled castes(SC) as compared to general caste. ${ }^{27}$ Another study of Orissa by RS Balgir (2005) observed that majority of hemoglobinopathic patients belong to general castes for sickle cell disorders $(64.6 \%), \beta$-thalasemia $(79.6 \%)$ and other hemoglobinopathies $(91.3 \%) .{ }^{8}$ This may be due to breeding isolation of the people from the general stream and strictly following the tribal endogamy. 


\section{CONCLUSION}

Our study was an attempt to study the prevalence of hemoglobinopathies in different regions and caste of Uttar Pradesh. The data regarding prevalence and distribution can be useful in prevention and management of various hemoglobinopathies which may play a vital role in the hospital blood bank as well as in the formulation of transfusion policies. Adequate measures and screening procedures should be performed concurrently. Thus, it can reduce the possibility of hemoglobin disorders of offspring, mental and physical trauma of affected patients and socio-economic burden of the family.

This \% data does not reflect the exact status of hemoglobinopathies in general population since this is a hospital based study. Further large scale population based studies are needed for real status of hemoglobinopathies in different caste and geographical area.

\section{REFERENCES}

1. Bittles $\mathrm{AH}$. Endogamy, consanguinity and community genetics. J Genet 2002; 81:91-98.

2. Meena VK, Kumar K, Meena LP, Bharti A and Kumar A. Screening for Hemoglobinopathies in blood donors from eastern Uttar Pradesh. National Journal of Medical Research 2012; 2(3): 366-368.

3. Prevalence of Haemoglobinopathies . Who- Executive Board EB118/5, 118th Session Report by the Secretariat on Thalassaemia and other haemoglobinopathies. 2006;1-8.

4. Guidelines for the control of haemoglobin disorders: report of the Vlth Annual Meeting of the WHO Working Group on Haemoglobinopathies. 1989 April 8-9; Cagliari, Sardinia, Geneva. World Health Organization (unpublished document WHO/HDP/WG/HA/89.2).

5. Ambek SS, Phadke MA, Mokashi GD, Bankar MP, Khedkar VA, Venkat $\mathrm{V}$, et al. Pattern of haemoglobinopathies in western Maharastra. Indian Pediatrics 2001; 38: 530-534.

6. Balgir RS. The burden of haemoglobinopathies in India and the challenges ahead. Curr Sci 2000; 79:1536-1547.

7. Balgir RS. The genetic burden of haemoglobinopathies with special reference to community health in India and the challenges ahead. Indian J Hematol Blood Transfus 2002; 20: 2-7.

8. Balgir RS. Spectrum of haemoglobinopathies in the state of Orissa, India: A ten years cohort study. J Assoc Physicians India 2005; 53: 1021-1026.

9. Verma IC, Saxena R, Thomas, E and Jain PK. Regional distribution of $b$-thalasemia Mutation in India. Hum Genet 1997; 100: 109-113.

10. Choudhury V, Kotwal J and Saxena R. Thalasemia screening and control programme. Pediatrics Today 1998; 1: 283-289.
11. Chakraborti BS and Sengupta B. Prenatal Diagnosis of Thalassaemias. Int J Hum Genet 2002; 2(3): 173-178.

12. Dacie JV and Lewis SM. Practical Hematology. 10th ed. Edinburgh: Churchill Livingstone ; 2006.

13. Daland GA and Castle WB. Simple and rapid method for demonstrating sickling of red blood cells use of reducing agents. J Lab Clin Med 1948; 53: 1082.

14. Weatherall DJ. The Thalasemias. In: Methods in Hematology. Vol 8. New York: Churchill Livingstone; 2001.

15. Varawalla NY, Old JM, Venkateshanz SR and Weatherall DJ. The spectrum of beta thalasemia mutations on the Indian subcontinent, the basis of prenatal diagnosis. Brit $\mathrm{J}$ Hematol 1991; 78: 242-247.

16. Balgir RS. Genetic epidemiology of the three predominant abnormal hemoglobins in India. J Assoc Physicians India 1996; 44: 25-28.

17. Dastidar GD, Dutta RN, Gupta P and Old JM. Detection of beta thalasemia muatations in Eastern Indian population by polymerase chain reaction. Indian J Med Res 1994; 100: 111-114.

18. Ambekar SS, Phadke MA, Balpande DN, Mokashi GD, V.A. Khedkar, Banker MP, et al. The Prevalence and heterogeneity of beta thalasemia mutations in the Western Maharashtra Population: A hospital based study. IJHG 2001; 1(3): 219-223.

19. Chopra GS, Nair V, Gupta PK, Mishra DK, Sharma A and Mathew OP. Spectrum of haemoglobinopathies in a tertiary care hospital of armed forces. Medical Journal Armed Forces India. 2008; 64(4): 311-314.

20. Patel J, Patel A, Patel J, Kaur A and Patel V. Prevalence of Haemoglobinopathies in Gujarat, India: A Cross-Sectional Study. The Internet J Hematol. 2009; 5: 1.

21. Patel J, Shrivastav A, Joshi JR, Agnihotri AS, Kaur A and Thakkar B. Detection of hemoglobinopathies and thalasemias in population of Gujarat State using HPLC: Analysis of 2022 cases. Pathology and Laboratory Medicine 2012; 4(2): 80- 84.

22. Panda A, Praveen B and Bisht SS. Clinical \& pathological status of haemoglobinopathies among pregnant women in southern Orissa. Indian Journal of Biotechnology 2009; 8(4): 456-457.

23. Sachdev R, Dam AR and Tyagi G. Detection of $H b$ variants and hemoglobinopathies in Indian population using HPLC: report of 2600 cases. Indian J Patho Microbiol 2010; 53(1): 57-62. doi: $10.4103 / 0377$.

24. Uddin MM, Akteruzzaman S, Rahman T, Hasan AK and Shekhar HU. Pattern of $\beta$-Thalasemia and Other Haemoglobinopathies: $A$ Cross-Sectional Study in Bangladesh. ISRN Hematology 2012; Article ID 659191.

25. Jain BB, Roy RN, Ghosh S, Ghosh T, Banerjee $U$ and Bhattacharya SK. Screening for thalasemia and other hemoglobinopathies in a tertiary care hospital of West Bengal: implications for population screening. Indian Journal of Public Health 2012; 56(4): 297-300.

26. Rao S, Kar R, Gupta SK, Chopra A and Saxena R. Spectrum of haemoglobinopathies diagnosed by cation exchange-HPLC \& modulating effects of nutritional deficiency anaemias from north India. Indian Journal of Medical Research 2010; 132(5): 513-19.

27. Bhasin MK, Walter H and Danker-Hopfe H. Glucose-6-phosphate dehydrogenase deficiency and abnormal hemoglobins ( $S$ and $E$ ) in people of India. J Hum Ecol 1994; 3:131-159.

\footnotetext{
Authors Contribution:

Dr. Pratima Verma and Akhilesh Krishna collected the samples and carried out all the experimental work. Over all supervision and Hypothesis was generated by Dr. Archana Ghildiayal. Dr. Ashutosh Kumar guided and supervised the experimental work of the study. Dr. Dileep Verma and Dr. Sunita Tiwari helped in the data management and statistical analysis. Dr. Shraddha Singh guided the screening of subjects and supervises all the work done in the study. All the authors were equally involved in drafting and finalizing the manuscript.

Source of Support: Authors are thankful to the Council of Science and Technology Lucknow Uttar Pradesh (Grant No. CST/D 3322).. We are also grateful to all the volunteers for their participation in the study., Conflict of Interest: None declared.
} 